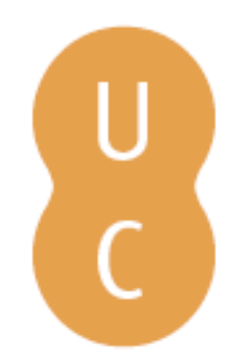

\title{
nombalina
}

\section{'Who do you think you are?': a critique of the concept of exceptionalism in the construction and analysis of American identity}

\author{
Autor(es): Wilson, Stephen \\ Publicado por: Imprensa da Universidade de Coimbra \\ URL \\ persistente: URI:http://hdl.handle.net/10316.2/43215 \\ DOI: $\quad$ DOI:https://doi.org/10.14195/978-989-26-1483-0_8 \\ Accessed : $\quad$ 26-Apr-2023 15:12:00
}

A navegação consulta e descarregamento dos títulos inseridos nas Bibliotecas Digitais UC Digitalis, UC Pombalina e UC Impactum, pressupõem a aceitação plena e sem reservas dos Termos e Condições de Uso destas Bibliotecas Digitais, disponíveis em https://digitalis.uc.pt/pt-pt/termos.

Conforme exposto nos referidos Termos e Condições de Uso, o descarregamento de títulos de acesso restrito requer uma licença válida de autorização devendo o utilizador aceder ao(s) documento(s) a partir de um endereço de IP da instituição detentora da supramencionada licença.

Ao utilizador é apenas permitido o descarregamento para uso pessoal, pelo que o emprego do(s) título(s) descarregado(s) para outro fim, designadamente comercial, carece de autorização do respetivo autor ou editor da obra.

Na medida em que todas as obras da UC Digitalis se encontram protegidas pelo Código do Direito de Autor e Direitos Conexos e demais legislação aplicável, toda a cópia, parcial ou total, deste documento, nos casos em que é legalmente admitida, deverá conter ou fazer-se acompanhar por este aviso.

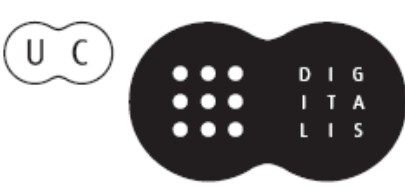




\section{IDENTITY(IES) A MULTICULTURAL AND MULTIDISCIPLINARY APPROACH}

\section{ANA PAULA ARNAUT \\ (ORG.)}

IMPRENSA DA UNIVERSIDADE DE COIMBRA

COIMBRA UNIVERSITY PRESS 


\section{'WHO DO YOU THINK YOU ARE?' : A CRITIQUE OF THE CONCEPT OF EXCEPTIONALISM IN THE CONSTRUCTIONANDANALYSIS OF AM ER I CAN I D E NTT I T Y}

Stephen Wilson University of Coimbra

Abstract: The view of America (and later the United States) as a place apart, essentially different, and the corollary tendency to see it as defined by that difference, is a longstanding one; it can be traced back to the discovery of the 'New World' (and arguably beyond). In 1630 the Puritan leader John Winthrop described the Massachusetts Bay Colony as a 'City upon a Hill' and warned the colonists that 'the eyes of all people are upon us.' Winthrop's words, and the entailed world view, have become part of American public discourse, and have persisted, with appropriate inflections, in the age of American empire and world hegemony. Such thinking is common to those who see themselves as pro- and anti-American, to the left and the right, to those who see the United States as the 'the world's last best hope' (the phrase is Abraham Lincoln's) and those who hold the United States to be 'the Great Satan.' My paper contests the usefulness of the concept of exceptionalism as an analytical tool and suggests that greater attention should 
be paid to continuities between the new and Old Worlds, between America and Europe and that in studying United States similarities are often as significant as differences.

Keywords: Excptionalism, the United States, Americaness, History

I will begin with some basic semantics. This is not so much an exercise in definition or clarification as an attempt to identify an area of ambiguity that is significant for my present purposes. Exceptional can mean departing or deviating from the norm, unusual, rare, and also better than the average, superior, of the highest quality; it signifies both difference and excellence or most often something that is both different and excellent (unusually bad weather could be described as exceptional but the term is more likely to be applied to unusually good weather). Attaching the suffix '-ism' introduces further declensions of meaning. Recourse to an online dictionary suggests a range of possibilities of which the following are the most apposite: an act, practice or process ('journalism') - a manner of action or behaviour or form of speech characteristic of a particular person or thing (a 'Spoonerism' or a 'Bushism') - a state, condition or property ('barbarianism') - a doctrine, theory or religion ('Catholicism?) adherence to a system or a class of principles or simply a system or a class of principles (structuralism). More specifically, but consistently with the range of meanings sketched out above, when applied to the field of American Studies 'exceptionalism' may denote both an analytical tool, a concept that claims to be useful in understanding and explaining many aspects of the United States, and an idea or belief system (one could say an ideology) that enters the domain of history with indicative, or even imperative, force. 
The term certainly has currency; indeed, it may be said to be enjoying something of a vogue. On 24 September 2013, addressing the United Nations, President Barack Obama, declared: 'I believe America is exceptional. In part because we have shown a willingness through the sacrifice of blood and treasure to stand up not only for our own narrow self-interest, but for the interest of all.' However, contemporary usage is inconsistent and even contradictory. In the post-Cold War years, the concept of exceptionalism was often invoked by all sides in discussion of the global hegemony of the United States. It could be argued that to hold the United States to be, in the words of Abraham Lincoln's Second Annual Message to Congress, 'the last best hope of earth', which is essentially what President Obama was asserting in the speech quoted above, and to see it as the 'Great Satan' are both examples of exceptionalism and so it is not merely being exceptional that is significant. In 2009. Donald Pearse published The New American Exceptionalism, a study of the United States post 9/11, in which he writes of 'the encompassing state of fantasy called American exceptionalism that had regulated U.S. citizens' relationship to the political order for the preceding half century' (Pearse, 2009: 1). To categorize exceptionalism' as a 'state fantasy' (a concept he derives somewhat reductively from Jacqueline Rose) is potentially interesting but all that finally emerges from the tortuous accounts given of the new exceptionalism is sense of a protean something or other that Pearse doesn't like.

The French writer Alexis de Tocqueville is generally held to have been the first to apply the adjective 'exceptional' to the United States and is accordingly sometimes said to be the first exceptionalist. In Democracy in America (1835/1840) de Tocqueville cautioned his readers that 'the position of the Americans is ... quite exceptional' in so far as 'their strictly Puritanical origin, their exclusively commercial habits' and 'a thousand special causes ... have singularly concurred to fix the mind of the American upon purely practical objects' 
(2: 36-7). Its claim to primacy gives de Tocqueville's use of the word 'exceptional' a degree of interest but I cannot see that here the word means much more than different.

More interestingly, in 1929 Stalin censured the Communist Party USA (CPUSA) for accepting the argument of the Pepper - Lovestone faction that the economic strength of American capitalism, the country's size and tremendous natural resources and the absence of a rigid class system made the United States resistant to the laws of history, as Marxists understood them, and so to revolution. Speaking in the American Commission of the Presidium of the Executive Committee of the Communist International in May 1929, Stalin condemned 'factionalism' and 'opportunism' and the heresy of 'exceptionalism'. Stalin conceded that while it 'would be wrong to ignore the specific peculiarities of American capitalism ... it would be still more wrong to base the activities of the Communist Party on these specific features, since the foundation of the activities of every Communist Party, including the American Communist Party ... must be the general features of capitalism, which are the same for all countries.' Stalin's view prevailed and the Wall St Crash and its aftermath restored the CPUSA to orthodoxy. John Pepper (born József Schwartz) submitted to party disciple and remained in Moscow to do work for the Communist International. He was executed in a purge in 1937 (or '38). Jay Lovestone (born Jacob Liebstein) left the Party and became a militant anti-Communist (in the 1950s he collaborated with the CIA).

If the Wall St Crash and its aftermath seemed to many observers to have vindicated Stalin, Franklin Delano Roosevelt's New Deal is often seen as triumph of exceptionalism: the New Deal was what Martin Walker termed an 'American solution', an alternative to a revolution or even to the emergence of a socialist movement. Walker is right to see Roosevelt as essentially a defender of the status quo, one who understood that if things were to remain the same they had to change (an American variation on British Conservative view 
that it is better to bend than to break). The New Deal was born out of a fear of revolution and, I would argue, should be understood an affirmation that the laws of history did indeed apply to the United States. Like Stalin, FDR did not believe in exceptionalism. There is also the possibility (and for me it is a deeply intriguing one) of another non-exceptionalist interpretation of the New Deal, one that see in the context of another set of laws of history - those formulated in the late $19^{\text {th }}$ and early $20^{\text {th }}$ century by Henry Adams and his brother Brooks who saw history as process of entropy.

That, however, is another story and a long one. For now, I would make the point that that what is at issue here is not simply difference, of course America is different from other places And other places are different from America) but the nature of that difference and how it is perceived, and on that basis I will examine briefly two canonical instances of exceptionalism.

John Winthrop (1587/8-1649), one of the leading figures in the founding of the Massachusetts Bay Colony, arrived in American colonies New England in 1630 at the head of as large party of Puritans. Before disembarking he preached a sermon - 'A Model of Christian Charity (1630 on board the Arbella)' - reminding the colonists that they had 'entered into covenant with [God) for this work' and that by bringing them safely across the Atlantic to their new home 'the Lord ... [had] ... ratified this covenant and sealed our commission' and warned them that they would now have to keep their side of the bargain. In a much-quoted passage he prophesised that:

... for wee must Consider that wee shall be as a Citty upon a Hill, the eyes of all people are uppon us; soe that if wee shall deal falsely with our god in this worke we have undertaken, and soe cause Him to withdrawe his present help from us, wee shall be made a story and a by-word through the world. (McQuade et al, 1: 149-150) 
This passage has been widely cited as the fons et origo of American exceptionalism and it is particularly highly regarded by conservatives and neoconservatives. Ronald Reagan was fond of it. For them the United States is the biblical 'Citty upon a Hill,' the New Jerusalem, set apart from, or even transcending, history. Winthrop is indeed claiming that the American colonists are an elect, a people chosen to build the New Jerusalem but that is not the same thing. Winthrop employed a figural or typological mode of narrative or argument in terms of which the American colonists, wanderers in the American wilderness, are the antitype of a number of Biblical types (most obviously, the Children of Israel wandering in the desert) and so they are not set aside from history, do not transcend it, but are the fulfilment of its grand narrative and as such they are not exceptional but exemplary.

It may further be noted that Winthrop's view of history is a somewhat conventional one in that it is fundamentally 'heliotropic'; that is to say that it sees the progress of religion, learning, society of humanity generally - as moving from east to west and so following or tracking the westward movement of the sun. The translatio imperii and the translatio studii, which are also, in their more orthodox and influential versions, beliotropic. These tropes generate a universal history in which America is an unexceptional event.

This point becomes even clearer if one looks at later secular versions of Winthrop's providential narrative such as Bishop Berkeley's 'Verses on the Prospect of Planting Arts and Learning in America':

Westward the course of empire takes its way;

The first four acts already past,

A fifth shall close the drama with the day;

Time's noblest offspring is the last. 
The peroration of J. Hector St. John Crèvecoeur's (1735-1813) 'What is an American' is perhaps better known:

Here individuals of all nations are melted into a new race of men, whose labours and posterity will one day cause great changes in the world. Americans are the western pilgrims, who are carrying along with them that great mass of arts, sciences, vigour, and industry which began long since in the east; they will finish the great circle. (Crèvecoeur, 1963: 64)

My second example is George Washington's Farewell Address to the American people. In it Washington exhorts his 'friends' and fellow 'citizens' (Americans 'by birth or choice') to cherish their Union and Constitution and 'to think and speak of it as of the palladium of your political safety', but above all he warns them to beware of foreign entanglements:

Against the insidious wiles of foreign influence (I conjure you to believe me, fellow-citizens) the jealousy of a free people ought to be constantly awake, since history and experience prove that foreign influence is one of the most baneful foes of republican government... adding that 'the great rule of conduct for us in regard to foreign nations is in extending our commercial relations, to have with them as little political connection as possible.

Washington was seeking to justify his policy of neutrality during the Napoleonic Wars but it is sometimes read as asserting that the United States is not just a new nation but a new type of nation that is above the wars and conflicts of the wicked old Europe:

Europe has a set of primary interests which to us have none; or a very remote relation. Hence she must be engaged in frequent 
controversies, the causes of which are essentially foreign to our concerns. Hence, therefore, it must be unwise in us to implicate ourselves by artificial ties in the ordinary vicissitudes of her politics, or the ordinary combinations and collisions of her friendships or enmities.

This sounds very well, even exceptional, but I suspect that, as I have said, Washington is presenting policy as principle and dressing up pragmatism and expedience in high sounding generalisations. Also, I cannot help noting that it is suspiciously similar to the traditional British policy of having no fixed principals only permanent interests, of remaining out of European wars but profiting by them whenever possible. Standing aloof from the fight, holding the coats of the combatants and picking their pockets. A policy that gave rise to the designation 'perfidious Albion'.

This point could be enlarged into a more general argument about the American Revolution itself. It is often presented as an exceptional and epochal event, the starting point of a Novus ordo seclorum, but it is also continuation of Britain's 'Glorious Revolution' of 1688. Garry Wills has noted that in colonial North America 'the Revolution' was Britain's 'Glorious Revolution' of 1688. To say this is not to deny that the American Revolution was an exceptional and epochal event but to recognise that events of the scope and complexity of the American Revolution can never be reduced to a single interpretation, even an exceptional one.

When the exceptional nature of the United States is invoked as the basis of policy or action it is never to be taken at face value although one must allow for the possibility that those making the claim are deceived as well as deceiving. I am sceptical in regard to the more the more extravagant claim that 'exceptionalism' somehow enters the historical field as an active and becomes a disembodied mischief that can be held responsible for 9/11, the War in Iraq, the 
election of Donald Trump and other misfortune. I would very much like to see an explanation of the mechanics of this process but so one has not been forthcoming. As a mode of explanation, it never tells the whole story and it is never a sufficient explanation or the only possible explanation. Of course, the United States is different and there are indeed aspects of its life and culture that could be described as distinctively or typically American such as a fondness for guns and a dislike for social medicine. Having said that when we look at it more closely we find that many Americans don't really like guns all that much and are quite fond of social medicine (the promise of it got Bill Clinton and Barack Obama elected and Republicans are not finding it easy to scrap Obamacare). It must also be recognised that the other side of the Atlantic is no longer the only site for the production of Americanness. I have been studying, writing about and teaching America for a long time and have found it to be many things but it is neither 'the last best hope of earth' or the 'Great Satan'. It is not exceptional. It is much more interesting than that.

\section{References}

Berkeley, George. Verses On the Prospect of Planting Arts and Learning in America (1728). Retrieved April 13, 2017 from http://americainclass.org/wp-content/ uploads/2014/02/2_BERKELEY-VERSES-ON-THE-PROSPECT-OF-PLANTING-ARTS-AND-LEARNING-IN-AMERICA.pdf

Crèvecoeur, J. Hector St. John (1963). Letters From An American Farmer and Sketches of Eigteehth Century America. New York: Signet Classics.

Lincoln, Abraham. Second Annual Message to Congress December 1, 1862. Retrieved April 10, 2017 from http://www.presidency.ucsb.edu/ws/?pid=29503

McQuade, D., Atwan, R., Banla, Kaplan, J., Minter, D., Tichi, C. and Vendler (1987). The Harper American Literature. 2 vols. New York: Harper and Row, Doubleday.

Obama, Barack. Remarks by President Obama in Address to the United Nations General Assembly. Retrieved April 10, 2017 from https://obamawhitehouse. archives.gov/the-press-office/2013/09/24/remarks-president-obama-address-united-nations-general-assembly

Pearse, Donald (2009). The New American Exceptionalism. Minneapolis \& London: $\mathrm{U}$ of Minnesota Press. 
Stalin, Joseph. Speech Delivered in the American Commission of the Presidium of the ECCI, May 6, 1929. Retrieved April 12, 2017 from https://www.marxists.org/ history/usa/parties/cpusa/1931/nomonth/0000-stalin-onamericanparty.pdf

Tocqueville, Alexis de. Democracy in America. 2 vols. Ed Phillips Bradley (1951). New York: Alfred A, Knopf.

Walker, Martin (2001). Makers of the American Century. London: Vintage.

Washington, George. Washington's Farewell Address, 1796. Retrieved April 11, 2017 from http://avalon.law.yale.edu/18th_century/washing.asp

Wills, Garry (1978). Inventing America. New York: Vintage Books. 